\title{
Screening and evaluation of the strong endogenous promoters in Pichia pastoris
}

\author{
Weiwang Dou ${ }^{1 \dagger}$, Quanchao Zhu ${ }^{1 \dagger}$, Meihua Zhang ${ }^{2}$, Zuyuan Jia ${ }^{1}$ and Wenjun Guan ${ }^{1 *}$ (D)
}

\begin{abstract}
Background: Due to its ability to perform fast and high-density fermentation, Pichia pastoris is not only used as an excellent host for heterologous protein expression but also exhibits good potential for efficient biosynthesis of smallmolecule compounds. However, basic research on P. pastoris lags far behind Saccharomyces cerevisiae, resulting in a lack of available biological elements. Especially, fewer strong endogenous promoter elements available for foreign protein expression or construction of biosynthetic pathways were carefully evaluated in P. pastoris. Thus, it will be necessary to identify more available endogenous promoters from P. pastoris.

Results: Based on RNA-seq and LacZ reporter system, eight strong endogenous promoters contributing to higher transcriptional expression levels and $\beta$-galactosidase activities in three frequently-used media were screened out. Among them, the transcriptional expression level contributed by $\mathrm{P}_{0019}, \mathrm{P}_{0107}, \mathrm{P}_{0230}, \mathrm{P}_{0392}$, or $\mathrm{P}_{0785}$ was basically unchanged during the logarithmic phase and stationary phase of growth. And the transcriptional level contributed by $\mathrm{P}_{0208}$ or $\mathrm{P}_{0627}$ exhibited a growth-dependent characteristic (a lower expression level during the logarithmic phase and a higher expression level during the stationary phase). After $60 \mathrm{~h}$ growth, the $\beta$-galactosidase activity contributed by $\mathrm{P}_{0208}, \mathrm{P}_{0627}, \mathrm{P}_{00191}, \mathrm{P}_{0407}, \mathrm{P}_{0392}, \mathrm{P}_{0230}, \mathrm{P}_{0785}$, or $\mathrm{P}_{0107}$ was relatively lower than $\mathrm{P}_{\text {GAP }}$ but higher than $\mathrm{P}_{\mathrm{ACT}}$. To evaluate the availability of these promoters, several of them were randomly applied to a heterogenous $\beta$-carotene biosynthetic pathway in P. pastoris, and the highest yield of $\beta$-carotene from these mutants was up to $1.07 \mathrm{mg} / \mathrm{g}$. In addition, simultaneously using the same promoter multiple times could result in a notable competitive effect, which might significantly lower the transcriptional expression level of the target gene.
\end{abstract}

Conclusions: The novel strong endogenous promoter identified in this study adds to the number of promoter elements available in P. pastoris. And the competitive effect observed here suggests that a careful pre-evaluation is needed when simultaneously and multiply using the same promoter in one yeast strain. This work also provides an effective strategy to identify more novel biological elements for engineering applications in P. pastoris.

Keywords: Pichia pastoris, Endogenous promoter, RNA-seq, $\beta$-Galactosidase, Biosynthetic pathway

\section{Background}

As one of the typical methylotrophic yeasts, Pichia pastoris (also known as Komagataella phaffii) is not only widely used as an excellent host for heterologous protein

\footnotetext{
*Correspondence: guanwj@zju.edu.cn

'Weiwang Dou and Quanchao Zhu contributed equally to this work ${ }^{1}$ Institute of Pharmaceutical Biotechnology and The Children's Hospital, Zhejiang University School of Medicine, Hangzhou 310058, China Full list of author information is available at the end of the article
}

expression [1] but also exhibits good potential for efficient biosynthesis of economic compounds such as nootkatone [2], carotenoids [3, 4], xanthophylls [5], ricinoleic acid [6], hyaluronic acid [7] and dammarenediol II [8]. Although a lot of work had been carried out in P. pastoris, compared with Saccharomyces cerevisiae, fewer strong endogenous promoter elements available for foreign protein expression or construction of biosynthetic pathways were carefully investigated in P. pastoris [9]. original author(s) and the source, provide a link to the Creative Commons licence, and indicate if changes were made. The images or other third party material in this article are included in the article's Creative Commons licence, unless indicated otherwise in a credit line to the material. If material is not included in the article's Creative Commons licence and your intended use is not permitted by statutory regulation or exceeds the permitted use, you will need to obtain permission directly from the copyright holder. To view a copy of this licence, visit http://creativecommons.org/licenses/by/4.0/. The Creative Commons Public Domain Dedication waiver (http://creativeco mmons.org/publicdomain/zero/1.0/) applies to the data made available in this article, unless otherwise stated in a credit line to the data. 
Using methanol as a carbon source is one of the most favorable properties of $P$. pastoris. Several promoters from the methanol utilization (MUT) pathway were identified as the methanol-dependent strong promoters [10], such as $\mathrm{P}_{\mathrm{AOX1}}$ (the promoter of alcohol oxidase 1) [11], $\mathrm{P}_{\mathrm{FLD} 1}$ (the promoter of formaldehyde dehydrogenase 1) [12], and $P_{D A S}$ (the promoter of dihydroxyacetone synthase) [13]. On the contrary, $\mathrm{P}_{\text {PEX8 }}$ (the promoter of peroxisomal matrix protein) [14] or $\mathrm{P}_{\mathrm{AOX} 2}$ (the promoter of alcohol oxidase 2) [15] was classified as a weak promoter. Considering that these promoters are tightly regulated by methanol, making them useful for the efficient production of foreign proteins when using methanol as a carbon source and inducer [16].

$\mathrm{P}_{\mathrm{GAP}}$ is the most frequently used constitutive promoter that drives the expression of glyceraldehyde-3-phosphate dehydrogenase at a high level in the medium with glucose or glycerol but at a moderate level in the medium with methanol as a carbon source. Although in many cases, $\mathrm{P}_{\mathrm{AOX} 1}$ works more efficiently than $\mathrm{P}_{\mathrm{GAP}}$ for heterologous protein production $[17,18]$. Some cases also gave the opposite results. Waterham HR et al. proved the expression level of $\beta$-lactamase contributed by $\mathrm{P}_{\mathrm{GAP}}$ in the medium containing glucose was even higher than $\mathrm{P}_{\mathrm{AOX} 1}$ in the medium containing methanol [19]. Similar result was obtained with the $\mathrm{P}_{\mathrm{GAP}}$ regulated mammalian peptide transporters rPEPT2 by Doring F et al. [20]. A promoter library of mutated $\mathrm{P}_{\mathrm{GAP}}$ was generated, and it spanned an activity range between $0.6 \%$ and 19.6 -fold of the wild-type $\mathrm{P}_{\mathrm{GAP}}$ activity [21]. As another well-known constitutive and strong promoter, the transcriptional activity of $\mathrm{P}_{\mathrm{TEF} 1}$, which controls the expression of translation elongation factor 1 alpha [22], was also found to be similar to or higher than that of $\mathrm{P}_{\mathrm{GAP}}$ in batch cultures or fed-batch cultures (glucose or glycerol was used as carbon source). $\mathrm{P}_{\mathrm{GCW} 14}$ is a strong constitutive promoter discovered recently [23]. It exhibited stronger promoter activity than $\mathrm{P}_{\mathrm{TEF} 1}$ or $\mathrm{P}_{\mathrm{GAP}}$ under different carbon sources (glucose, glycerol, or methanol) when an enhanced green fluorescent protein (EGFP) was used as the reporter. Moreover, some other constitutive promoters, $\mathrm{P}_{\mathrm{ENO} 1}$, $\mathrm{P}_{\mathrm{GPM} 1}, \mathrm{P}_{\mathrm{HSP} 82}, \mathrm{P}_{\mathrm{KAR} 2}, \mathrm{P}_{\mathrm{PGK} 1}, \mathrm{P}_{\mathrm{SSA} 4}$, and $\mathrm{P}_{\mathrm{TPI} 1}$ [24], were also reported with little attention paid. The expression levels of EGFP contributed by these promoters were showed to be $10-80 \%$ of that of $\mathrm{P}_{\mathrm{GAP}}$.

Although most studies have focused on strong promoters, it is worth noting that strong promoters are not suitable in some applications. For example, promoters with moderate expression levels are sometimes more desirable for transporter or chaperone expression. Thus, the studies on various promoters with different transcriptional activities should also be emphasized. In this study, based on the RNA-seq data and LacZ reporter system, eight novel endogenous promoters that exhibited strong transcriptional activities in three frequently-used media were screened out. A heterogenous $\beta$-carotene biosynthetic pathway was chosen to further evaluate the availability of these promoters. It was also found that simultaneously using the same promoter multiple times could result in a notable competitive effect, which might significantly lower the transcriptional expression level of the target gene.

\section{Results}

\section{Screening the potential strong promoters independent of carbon sources based on RNA-seq}

In order to screen out strong promoter candidates from P. pastoris, the assessment of cell growth status was firstly carried out. As shown in Fig. 1A, the yeast cells gradually entered the stationary phase after $36 \mathrm{~h}$ growth in YPD, YPG, or YPM broth. Considering that the accumulation of protein expression or small-molecule compound has occurred chiefly during the stationary phase of yeast growth, total RNA isolation and subsequent RNA-seq were performed after $36 \mathrm{~h}$ growth.

As shown in Fig. 1B, the distribution of FPKM (referred to fragments per kilobase of transcript per million base pairs sequenced) values of genes was similar when the GS115 WT strain was cultured in three broths, and the FPKM values of most genes fall in the range of 10-50. The FPKM value of ACT1 (PAS chr3_1169), which is usually used as an endogenous reference gene (housekeeping gene) in yeast $[25,26]$, was 624 in YPD, 858 in YPG, and 315 in YPM, respectively. It ranked 245th out of 4764 (YPD), 185th out of 4897 (YPG), and 473th out of 4410 (YPM) expressed genes $(\mathrm{FPKM}<10$ was defined as not expressed in the corresponding medium), indicating that $\mathrm{P}_{\mathrm{ACT} 1}$ could be considered as a strong promoter. To explore the potential strong promoters in all the above media, the genes with FPKM values five times higher than that of $A C T 1$ were selected as the candidate genes. Finally, the promoters of PAS_chr1-4_0586 (GCW14), PAS_chr4_0627, PAS_chr2-2_0019, PAS_chr2-1_0437 (GAP), PAS_chr11_0407, PAS_chr2-2_0392, PAS_chr3_0230, PAS_chr22_0208, PAS_chr4_0785, and PAS_chr1-1_0107 were screened out (Additional file 1). For the subsequent description's convenience, the above genes were represented by GCW14, 0627, 0019, GAP, 0407, 0392, $0230,0208,0785$, and 0107 , respectively. In addition, the expression levels of these candidate genes were also confirmed by real-time quantitative PCR (RT-qPCR). As shown in Fig. 1C, all the RT-qPCR results were consistent with the RNA-seq data, suggesting these promoters could be used for further evaluation. 

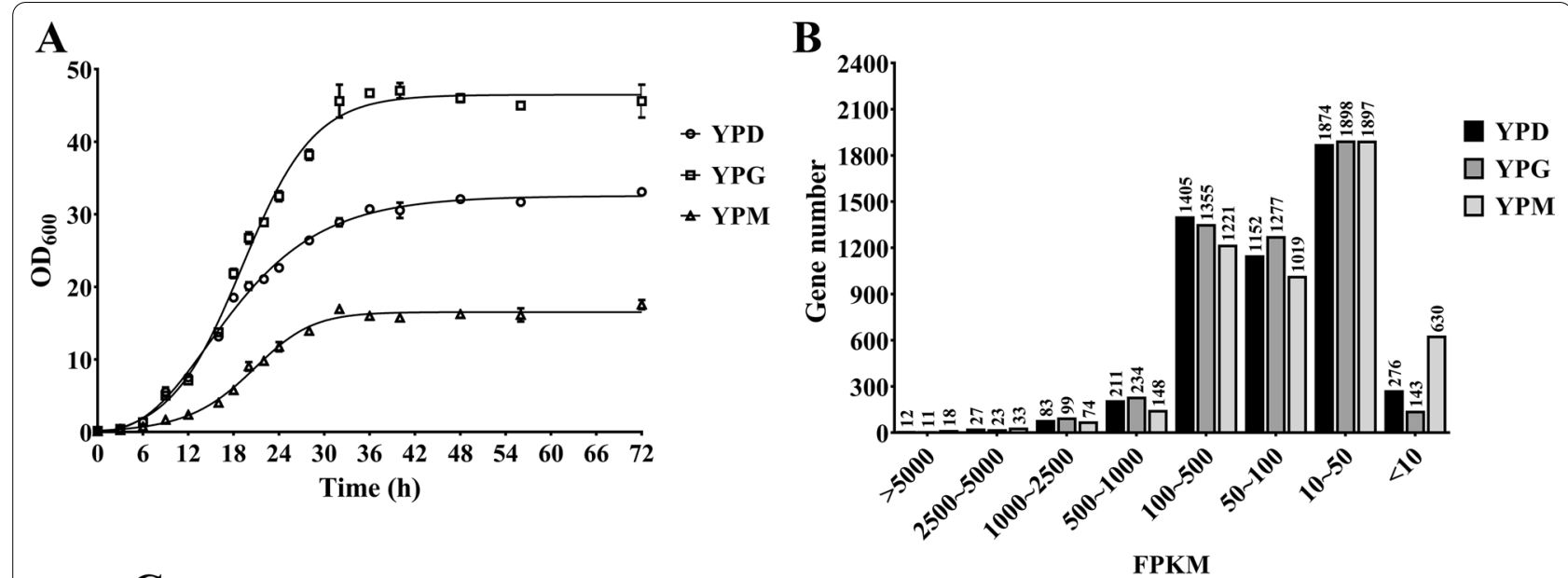

C

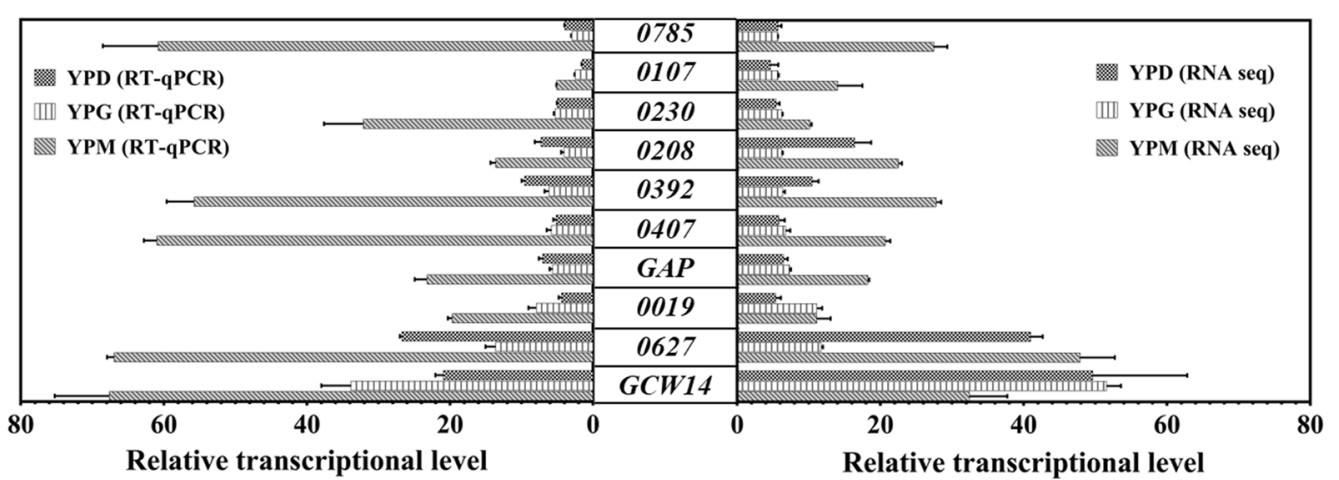

Fig. 1 Screening of the strong endogenous promoters based on RNA-seq. A The growth curves of P. pastoris GS115 WT strain in YPD, YPG, or YPM broth for $72 \mathrm{~h}$ with an initial $\mathrm{OD}_{600}$ of 0.15 . B The distribution of FPKM values of all expressed genes in three broths. C The RNA-seq and RT-qPCR data of candidate genes at $36 \mathrm{~h}$. Error bars indicate the SD for samples tested in triplicate

\section{Comparing the transcriptional activities of promoter candidates}

In order to compare the transcriptional activities of above-selected promoters, the $\beta$-galactosidase activities of transformants harboring vector pZeocin/ $\mathrm{P}_{\mathrm{XXX}}$-lacZ- $\mathrm{T}_{\mathrm{ADH} 1}\left(\mathrm{P}_{\mathrm{XXX}}\right.$ indicates the name of candidate promoter) were measured after $60 \mathrm{~h}$ growth. The transcriptional levels of $l a c Z$ in all transformants were also tested by RT-qPCR. All experimental data was obtained from three independently screened colonies. As shown in Fig. 2, the $\beta$-galactosidase activity contributed by each selected promoter was higher than that by $\mathrm{P}_{\mathrm{ACT} 1}$ when the transformant was cultured in three mentioned broths, except $\mathrm{P}_{0107}$ which exhibited a lower $\beta$-galactosidase activity compared to $\mathrm{P}_{\mathrm{ACT} 1}$ in YPM broth. In YPD or YPG broth, the activity of $\mathrm{P}_{\mathrm{GAP}}$ or $\mathrm{P}_{\mathrm{GCW} 14}$ was significantly higher than those of the rest promoters. In YPM broth, $\mathrm{P}_{\mathrm{GCW} 14}$ contributed the highest $\beta$-galactosidase activity among the allselected promoters, and $\mathrm{P}_{\mathrm{GAP}}, \mathrm{P}_{0208}, \mathrm{P}_{0019}, \mathrm{P}_{0392}, \mathrm{P}_{0230}$, or $\mathrm{P}_{0627}$ contributed a similar $\beta$-galactosidase activity.
In summary, among the ten selected promoters, the previously reported $\mathrm{P}_{\mathrm{GAP}}$ and $\mathrm{P}_{\mathrm{GCW} 14}$ showed strong transcriptional activities. The transcriptional activity of $\mathrm{P}_{0019}, \mathrm{P}_{0107}, \mathrm{P}_{0208}, \mathrm{P}_{0230}, \mathrm{P}_{0392}, \mathrm{P}_{0407}, \mathrm{P}_{0627}$, or $\mathrm{P}_{0785}$ was between that of strong promoters $\mathrm{P}_{\mathrm{GAP}}$ and $\mathrm{P}_{\mathrm{ACT} 1}$. It indicates that these promoter candidates could be recognized as strong endogenous promoters in P. pastoris.

Although the transcriptional activities of most selected promoters corresponded with the $\beta$-galactosidase activities at $60 \mathrm{~h}$, there were still few exceptions, such as $\mathrm{P}_{0407}$ and $\mathrm{P}_{0230}$. For example, the transcriptional level of $\mathrm{P}_{0407}-l a c Z$ was much higher than that of $\mathrm{P}_{\mathrm{GAP}}-l a c Z$ when the relative transformants were cultured in YPG or YPM broth. However, the $\beta$-galactosidase activities controlled by $\mathrm{P}_{0407}$ were less than half of that by $\mathrm{P}_{\mathrm{GAP}}$. So was $\mathrm{P}_{0230}$-lacZ. We evaluated the copy number of lacZ controlled by each promoter, the results proved all clones harboring only one $l a c Z$, eliminating the influence of transcriptional level by copy number (data not shown). It indicated that the transcriptional and protein level were not coordinated in some genes. The reason was not clear. 

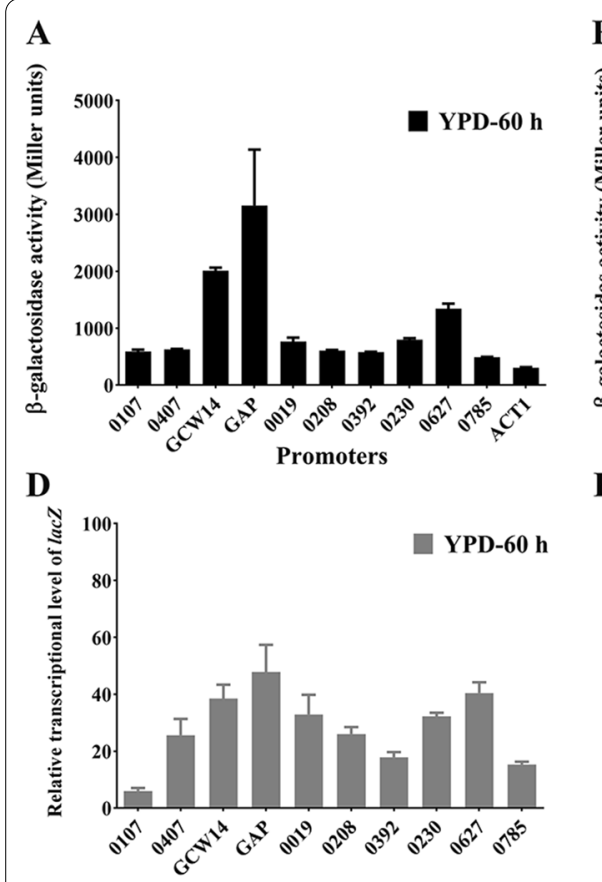

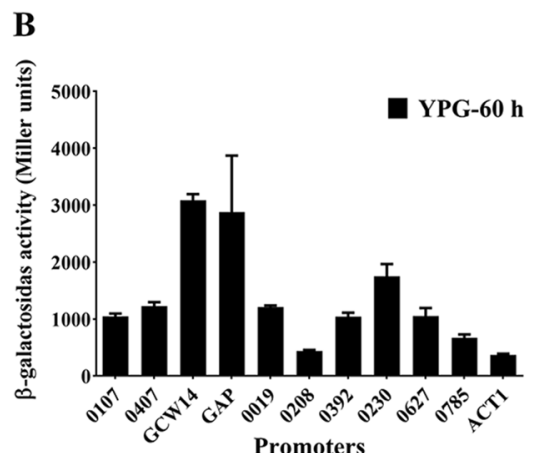

E

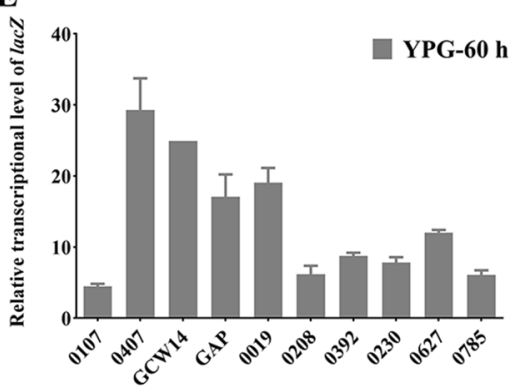

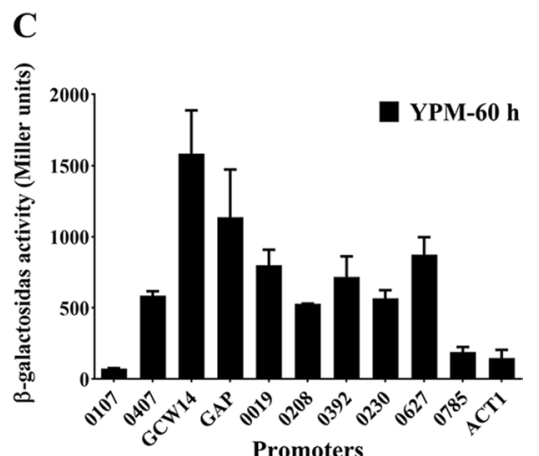

F

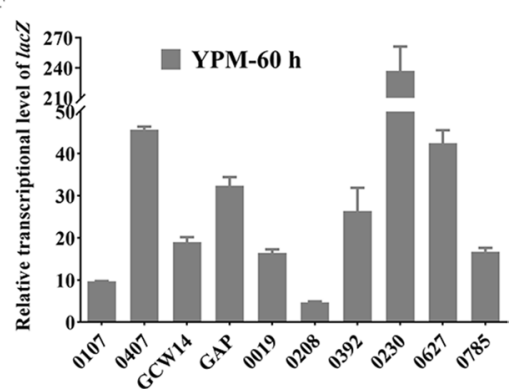

Fig. 2 Comparison of the selected promoter activities. A-C The $\beta$-galactosidase activity of transformant harboring vector $p Z$ Zeocin/P ${ }_{x x x}-a_{a C Z}-T_{A D H}$ $\left(P_{X X X}\right.$ indicates the name of candidate promoter) after $60 \mathrm{~h}$ growth. $\mathbf{D}-\mathbf{F}$ The relative transcriptional levels of lac $Z$ in different transformants. The $A C T 1$ gene was used as the reference gene. Error bars indicate the SD for samples tested in triplicate

$P_{0208}$ and $P_{0627}$ are novel growth-dependent promoters To evaluate whether the above promoters are constitutive, the $\beta$-galactosidase activities of different transformants at $16 \mathrm{~h}$ (exponential phase) and $60 \mathrm{~h}$ (stationary phase) were measured. In view of $\mathrm{P}_{\mathrm{GAP}}$ being identified as a recognized constitutive promoter, it was chosen as a control in this study. As shown in Table 1, most promoter candidates, except $\mathrm{P}_{0407}, \mathrm{P}_{0627}$, and $\mathrm{P}_{0208}$, could be defined as constitutive promoters due to their relatively stable $\beta$-galactosidase activities at 16 and $60 \mathrm{~h}$. The relative $\beta$-galactosidase activity driven by $\mathrm{P}_{0208}, \mathrm{P}_{0407}$, or $\mathrm{P}_{0627}$ at $16 \mathrm{~h}$ was at least $16.5,2.5$ or 7.5 times lower than that at $60 \mathrm{~h}$ in three media, reminding us that these promoters might be associated with cell growth.

To test this possibility, the transcriptional levels of 0407, 0208, and 0627 genes in the GS115 WT strain were detected at the different growth stages. As shown in Additional file 2, the transcriptional levels of 0407, 0627 and 0208 genes increased along with the growth time of GS115 WT strain in YPD and YPG

Table 1 The relative $\beta$-galactosidase activities driven by the selected promoters compared with $P_{G A P}$

\begin{tabular}{|c|c|c|c|c|c|c|}
\hline Promoters & $\begin{array}{l}\text { YPD } \\
16 \mathrm{~h}(\%)\end{array}$ & $\begin{array}{l}\text { YPD } \\
60 \mathrm{~h}(\%)\end{array}$ & $\begin{array}{l}\text { YPG } \\
16 \mathrm{~h}(\%)\end{array}$ & $\begin{array}{l}\text { YPG } \\
60 \mathrm{~h}(\%)\end{array}$ & $\begin{array}{l}\text { YPM } \\
16 \mathrm{~h}(\%)\end{array}$ & $\begin{array}{l}\text { YPM } \\
60 \mathrm{~h}(\%)\end{array}$ \\
\hline$P_{\text {GAP }}$ & 100.00 & 100.00 & 100.00 & 100.00 & 100.00 & 100.00 \\
\hline$P_{A C T 1}$ & 17.48 & 11.25 & 18.78 & 15.77 & 30.43 & 15.48 \\
\hline$P_{G C W 14}$ & 88.74 & 74.51 & 131.99 & 132.30 & 162.67 & 165.46 \\
\hline$P_{0019}$ & 27.51 & 28.25 & 36.94 & 51.98 & 88.92 & 83.48 \\
\hline$P_{0107}$ & 30.57 & 21.95 & 32.84 & 44.90 & 6.76 & 7.59 \\
\hline$P_{0230}$ & 30.15 & 29.49 & 42.96 & 75.11 & 54.56 & 59.04 \\
\hline$P_{0392}$ & 13.39 & 21.47 & 23.55 & 44.67 & 59.76 & 74.83 \\
\hline$P_{0785}$ & 19.09 & 18.23 & 19.52 & 28.66 & 34.18 & 19.71 \\
\hline$P_{0208}$ & 0.53 & 22.52 & 1.14 & 18.76 & 0.60 & 55.25 \\
\hline$P_{0407}$ & 7.92 & 23.23 & 19.13 & 52.61 & 8.26 & 61.18 \\
\hline$P_{0627}$ & 6.29 & 49.65 & 5.99 & 45.05 & 7.87 & 91.24 \\
\hline
\end{tabular}


media, indicating $\mathrm{P}_{0407}, \mathrm{P}_{0208}$ and $\mathrm{P}_{0627}$ could be considered as growth-dependent promoters. In YPM broth, they behaved not growth-dependent at $60 \mathrm{~h}$. We suspect that it may be related to the depletion of carbon source (methanol). In our study, YPD (2\%), YPG (2\%) or YPM (1\%) has 32.58, 33.36 and $12.26 \mathrm{mmol}$ carbon atoms, respectively. At $60 \mathrm{~h}$, the methanol had been depleted which may affect the cell metabolism, so the relative transcriptional level of 0627,0407 and 0208 at $60 \mathrm{~h}$ was lower than that at $36 \mathrm{~h}$, showing non-growthdependent characteristic. From 16 to $36 \mathrm{~h}$, the relative transcriptional level was increased. Throughout the performance of 0208 and 0627 in three media for three time points, it demonstrates that they are growthdependent. In addition, the transcriptional level of 0407 was higher than that of $A C T 1$ at $16 \mathrm{~h}$ in YPD, YPG and YPM (Additional file 2), indicating $\mathrm{P}_{0407}$ was not a strictly growth-dependent promoter.

To further investigate the transcriptional properties of $\mathrm{P}_{0208}$ and $\mathrm{P}_{0627}$, the GS115/ $\mathrm{P}_{0208}$-lacZ- $\mathrm{T}_{\mathrm{ADH} 1}$ and GS115/ $\mathrm{P}_{0627}$-lacZ- $\mathrm{T}_{\mathrm{ADH} 1}$ strains were cultured in YPD broth and sampled every $12 \mathrm{~h}$ from $12 \mathrm{~h}$ to $60 \mathrm{~h}$. It was found that the relative transcriptional level of $\mathrm{P}_{0208}$ was increased from 0.002 to $16 \mathrm{~h}$ to 26 at $60 \mathrm{~h}$, while that of $\mathrm{P}_{0627}$ was increased from 0.005 to $16 \mathrm{~h}$ to 40 at $60 \mathrm{~h}$ (Fig. 3A). Although the growth status of GS115/ $\mathrm{P}_{0208}$-lacZ- $\mathrm{T}_{\mathrm{ADH1}}$ or $\mathrm{GS} 115 / \mathrm{P}_{0627}$-lacZ- $\mathrm{T}_{\mathrm{ADH} 1}$ strain was similar, the $\beta$-galactosidase activity of $\mathrm{GS} 115 / \mathrm{P}_{0208^{-}}$ lacZ- $\mathrm{T}_{\mathrm{ADH1}}$ strain was lower than that of $\mathrm{GS} 115 / \mathrm{P}_{0627^{-}}$ lacZ- $\mathrm{T}_{\mathrm{ADH} 1}$ strain at each sampling point (Fig. $3 \mathrm{~B}$ ), suggesting that $\mathrm{P}_{0627}$ has good potential to be used in expressing the toxic proteins independent of methanol induction.

\section{Evaluation of the promoter candidates through the heterogenous $\beta$-carotene biosynthetic pathway}

According to the previous report, the optimized $\beta$-carotene biosynthetic pathway always includes four genes, crtE/tHMG1/crtYB/crtI [27]. In this study, six promoter candidates $\left(\mathrm{P}_{\mathrm{GAP}}, \mathrm{P}_{\mathrm{GCW} 14}, \mathrm{P}_{0208}, \mathrm{P}_{0019}, \mathrm{P}_{0230}\right.$, and $\mathrm{P}_{0107}$ ) with different transcriptional activities were randomly selected and applied to the $\beta$-carotene biosynthetic pathway to further evaluate the availability of promoters. As shown in Fig. 4, a promoter library was first constructed by random linkage of two reverse-aligned promoters (Step 1). Then two vectors ( $\mathrm{pZeocin} / \mathrm{P}_{\mathrm{XXX}}{ }^{-}$ $c r t E-\mathrm{P}_{\mathrm{YYY}}-t H M G 1$ and $\mathrm{pG} 418 / \mathrm{P}_{\mathrm{XXX}}-c r t Y B-\mathrm{P}_{\mathrm{YYY}}-c r t I$, $\mathrm{P}_{\mathrm{XXX}}$ and $\mathrm{P}_{\mathrm{YYY}}$ indicate the name of candidate promoters) containing the above four genes were constructed (Step 2) and transformed into the GS115 WT strain in turn (Step 3). The promoter activities were qualitatively observed by the color of the transformants on plates (Step 4) and then quantitively determined by liquid fermentation (Step 5).

Finally, fourteen transformants with significant color differences were screened out for further liquid fermentation (Fig. 5A). The result indicates that the darker the color of transformant, the higher the yield of $\beta$-carotene (Fig. 5B). And the yield of $\beta$-carotene from these yeast mutants was from $0.0123 \mathrm{mg} / \mathrm{g}$ DCW (Caro-1 strain) up to $1.07 \mathrm{mg} / \mathrm{g}$ DCW (Caro-14 strain).
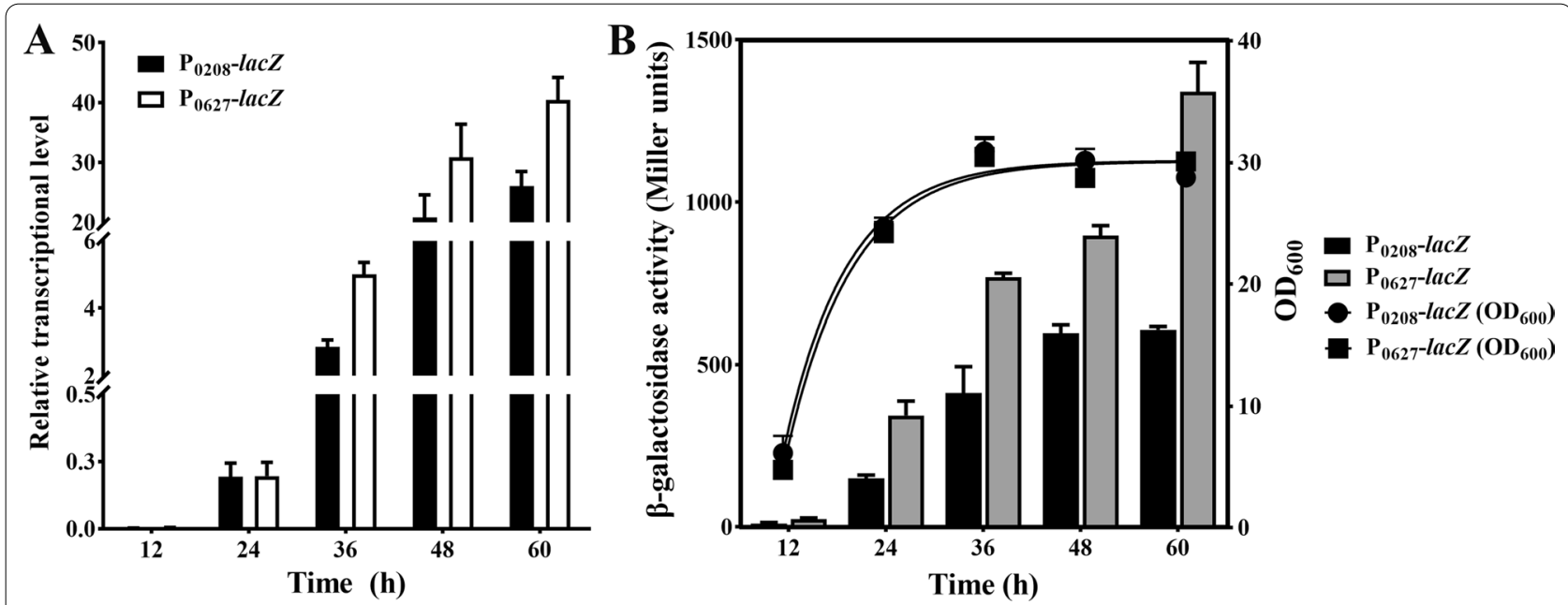

Fig. 3 The properties of $\mathrm{P}_{0208}$ and $\mathrm{P}_{0627}$. A The relative transcriptional level of $\mathrm{P}_{0208}$-lac $Z$ or $\mathrm{P}_{0627}$-lac $\mathrm{Z}$ after $12-60 \mathrm{~h}$ growth in $\mathrm{YPD}$ broth. The $A C T 1$

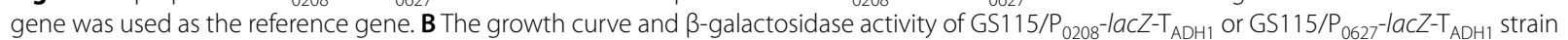
cultured in YPD broth. Error bars indicate the SD for samples tested in triplicate 


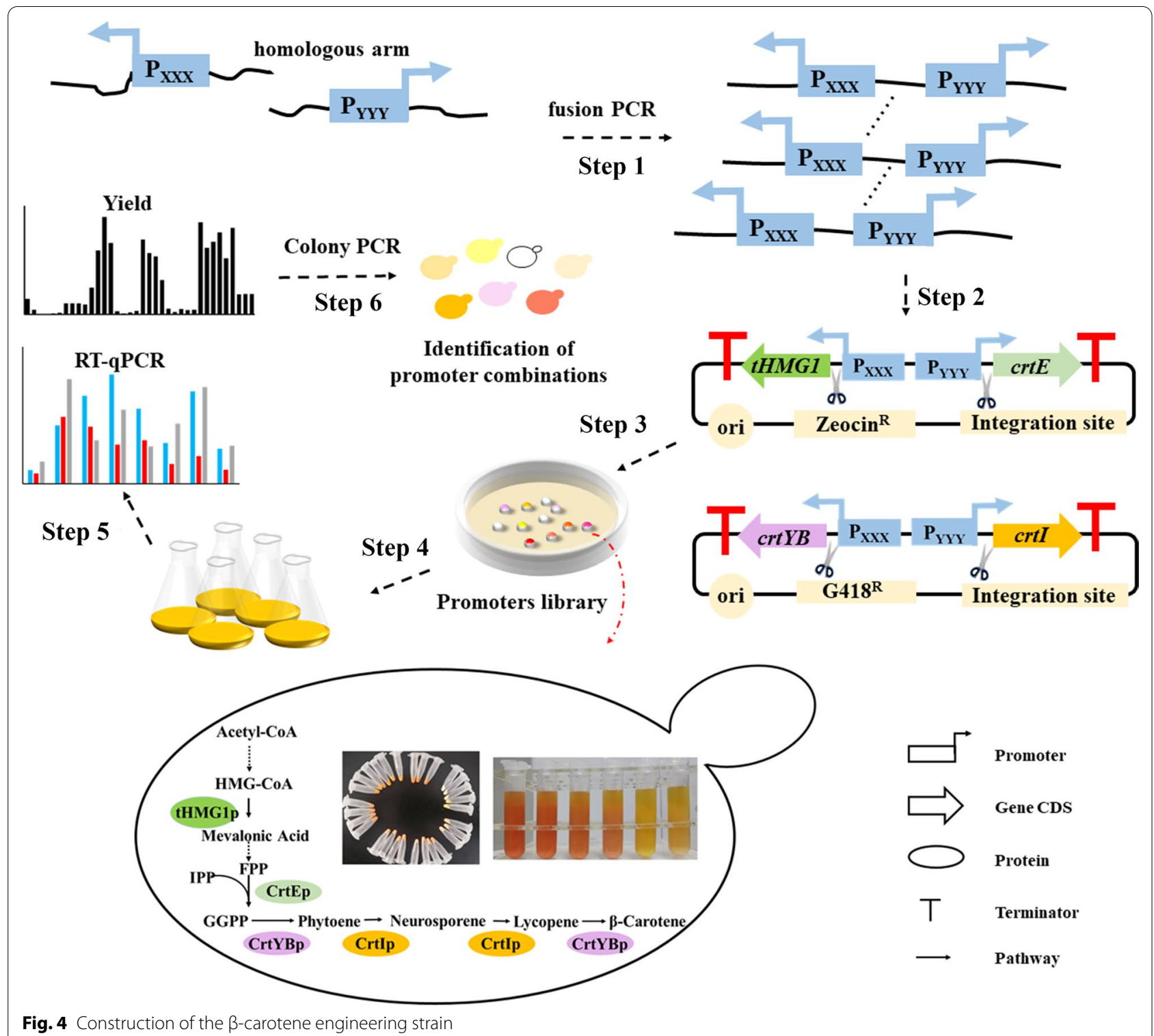

Fig. 4 Construction of the $\beta$-carotene engineering strain

The promoters of four genes ( $c r t E, t H M G 1, \operatorname{cr} t Y B$, and $(r t I)$ in each strain were verified by PCR and the primers were shown in Additional file 3. The relationship between the transcriptional activity of each gene and the $\beta$-carotene production of the engineering strain was then analyzed. As shown in Fig. 5C, when both $\operatorname{crt} Y B$ and $\operatorname{crtI}$ had a stronger promoter (similar to $\mathrm{P}_{\mathrm{GAP}}$ ), the $\beta$-carotene production of engineered strain was generally higher, and when $\operatorname{crt} Y B$ had a relatively weaker promoter compared to $\mathrm{P}_{\mathrm{GAP}}$, the $\beta$-carotene production of engineered strain was decreased. This result was consistent with the previous report that CrtYBp was the rate-limiting enzyme in $\beta$-carotene production [28]. Compared to the promoter combinations in the $\beta$-carotene biosynthetic pathway of Caro13 and Caro-14 strain, all corresponding genes used the same promoter except $c r t E$. The promoter of $\operatorname{crt} E$ was $\mathrm{P}_{\mathrm{GAP}}$ in the Caro-13 strain and $\mathrm{P}_{0230}$ in the Caro14 strain. Although the transcriptional activity of $\mathrm{P}_{0230}$ was lower than that of $\mathrm{P}_{\mathrm{GAP}}$ at $60 \mathrm{~h}$, the $\beta$-carotene production of the Caro-14 strain was much higher than that of the Caro-13 strain. This result suggested that not all genes should have stronger transcriptional levels to achieve higher $\beta$-carotene production. Balancing the expression level of each gene in the biosynthetic pathway could be a better choice. 


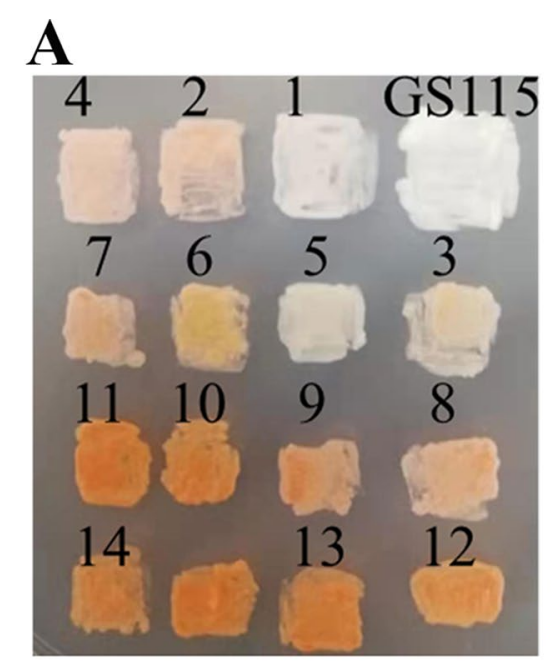

\section{B}

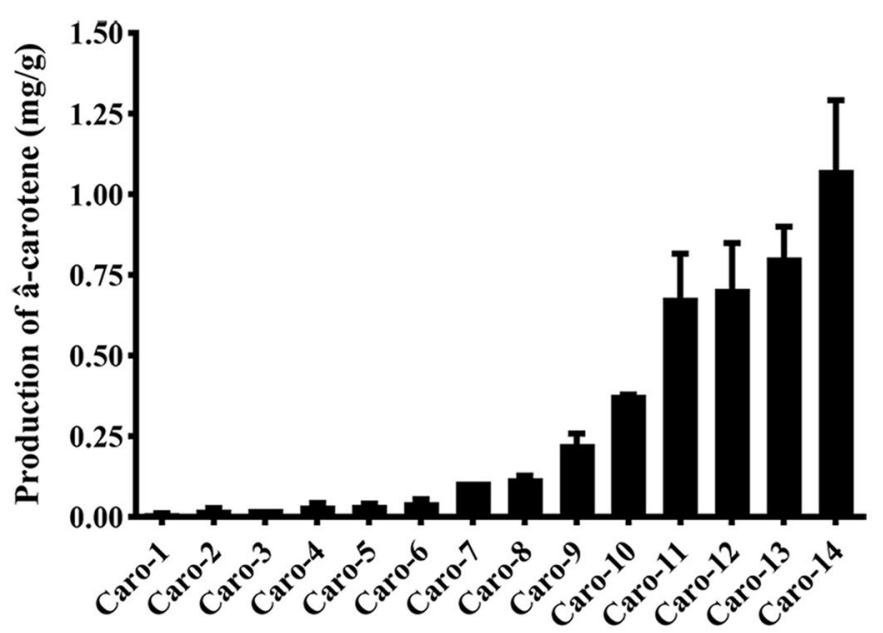

Strains

\begin{tabular}{|c|c|c|c|c|}
\hline & $M$ & $r t E$ & $\operatorname{crt} Y B$ & crtI \\
\hline & $\mathbf{P}_{0107}$ & $\mathbf{P}_{\text {GCWl4 }}$ & $\mathbf{P}_{0208}$ & $\mathbf{P}_{0107}$ \\
\hline 2 & $\mathbf{P}_{0107}$ & $\mathbf{P}_{0019}$ & $P_{0107}$ & $\mathbf{P}_{\mathrm{GAP}}$ \\
\hline & $\mathbf{P}_{\mathrm{GAP}}$ & $\mathbf{P}_{0208}$ & $\mathbf{P}_{0019}$ & $\mathbf{P}_{0107}$ \\
\hline 4 & $\mathbf{P}_{0107}$ & $\mathbf{P}_{0230}$ & $\mathbf{P}_{0230}$ & $\mathbf{P}_{\mathrm{GAP}}$ \\
\hline 5 & $\mathbf{P}_{\mathrm{GAP}}$ & $\mathbf{P}_{0203}$ & $\mathbf{P}_{0230}$ & $P_{0208}$ \\
\hline & $\mathbf{P}_{\mathrm{GAP}}$ & $\mathbf{P}_{0230}$ & $\mathbf{P}_{0230}$ & $\mathbf{P}_{\mathrm{GAP}}$ \\
\hline $7-$ & $\mathbf{P}_{\text {GCWl4 }}$ & $\mathbf{P}_{0230}$ & $\mathbf{P}_{0107}$ & $\mathbf{P}_{\mathrm{GAP}}$ \\
\hline $8-$ & $\mathbf{P}_{\text {GCW14 }}$ & $\mathbf{P}_{\mathrm{GAP}}$ & $\mathbf{P}_{0107}$ & $\mathbf{P}_{\mathrm{GAP}}$ \\
\hline $9-$ & $\mathbf{P}_{\text {GCW14 }}$ & $\mathbf{P}_{\mathrm{GAP}}$ & $\mathbf{P}_{\mathrm{GCW} 14}$ & $\mathbf{P}_{\mathrm{GAP}}$ \\
\hline $10-$ & $\mathbf{P}_{0107}$ & $\mathbf{P}_{0019}$ & $\mathbf{P}_{\mathrm{GAP}}$ & $\mathbf{P}_{\mathrm{GCW} 14}$ \\
\hline $11-$ & $\mathbf{P}_{0107}$ & $\mathbf{P}_{\mathrm{GCW} 14}$ & $\mathbf{P}_{\mathrm{GAP}}$ & $\mathbf{P}_{\mathrm{GCW} / 4}$ \\
\hline $12-$ & $\mathbf{P}_{\mathrm{GAP}}$ & $\mathbf{P}_{0230}$ & $\mathbf{P}_{\mathrm{GAP}}$ & $\mathbf{P}_{\text {GCW14 }}$ \\
\hline & $\mathbf{P}_{\text {GCWI4 }}$ & $\mathbf{P}_{\mathrm{GAP}}$ & $\mathbf{P}_{\mathrm{GAP}}$ & $\mathbf{P}_{\mathrm{GCW} 14}$ \\
\hline $14-$ & $\mathbf{P}_{\text {GCWI4 }}$ & $\mathbf{P}_{0230}$ & $\mathbf{P}_{\mathrm{GAP}}$ & $\mathbf{P}_{\text {GCW14 }}$ \\
\hline
\end{tabular}
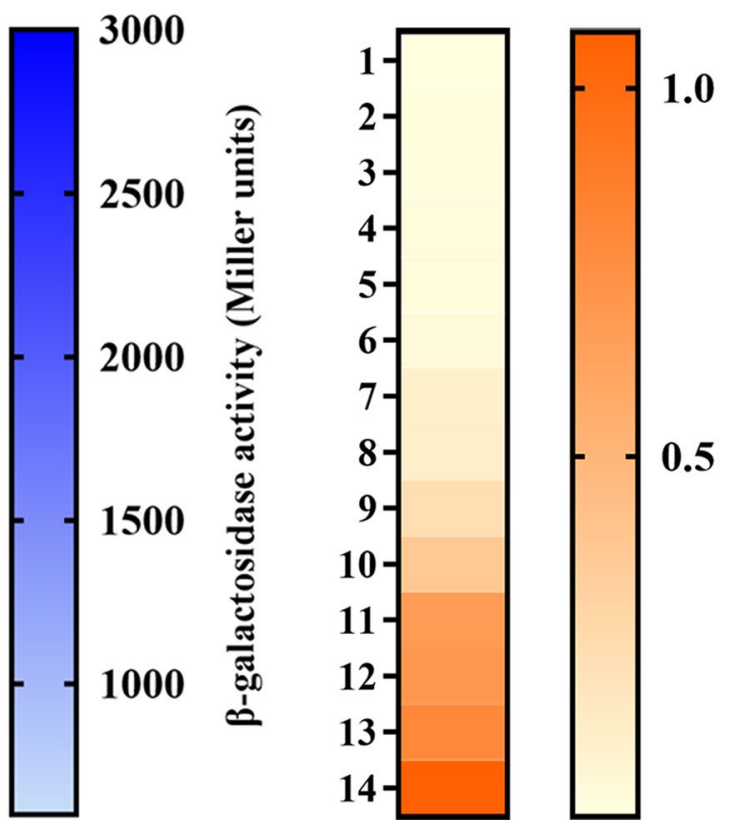

Fig. 5 Evaluation of the promoter candidates through the $\beta$-carotene biosynthetic pathway. A The fourteen engineering strains with significant color differences grown on the YPD agar plate. B The production of $\beta$-carotene of the selected engineering strains. Error bars indicate the SD for samples tested in triplicate. $\mathbf{C}$ Heat map of the transcriptional levels (blue) and the $\beta$-carotene productions (orange)

The existence of a significant competitive effect when one promoter was used multiple times in a yeast strain In the Caro-9 strain, the combination of exogenous genes and promoters was $\mathrm{P}_{\mathrm{GCW} 14^{-}}-t H M G 1 / \mathrm{P}_{\mathrm{GAP}^{-}}$

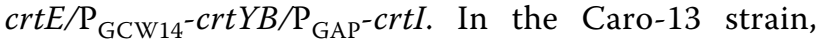
that was $\mathrm{P}_{\mathrm{GCW} 14^{-}}-t H M G 1 / \mathrm{P}_{\mathrm{GAP}}-c r t E / \mathrm{P}_{\mathrm{GCW} 14^{-}}-c r t / \mathrm{P}_{\mathrm{GAP}^{-}}$ crtYB. Although both $\mathrm{P}_{\mathrm{GAP}}$ and $\mathrm{P}_{\mathrm{GCW} 14}$ were strong promoters, and their related $\beta$-galactosidase activities were similar (Table 1 ), the $\beta$-carotene production of Caro-9 strain was over 3-fold lower than that of Caro-13 strain (Fig. 6A, B). The RT-qPCR result at $16 \mathrm{~h}$ also showed that the transcriptional level of $\operatorname{crt} Y B$ in the Caro-13 strain was over 3-fold higher than that in the Caro-9 strain (Fig. 6C). To figure out the reason, the transcriptional levels of four genes in the Caro-9 or Caro13 strain were measured, respectively. Accidentally, 


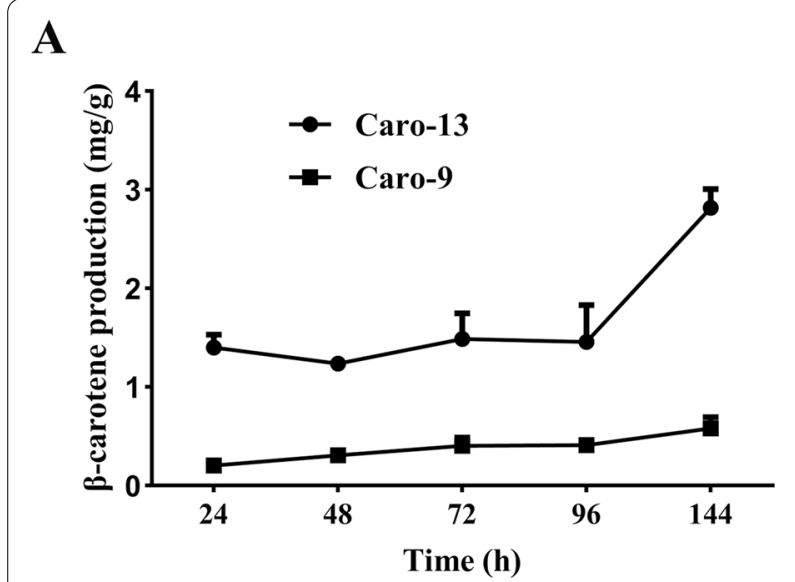

B
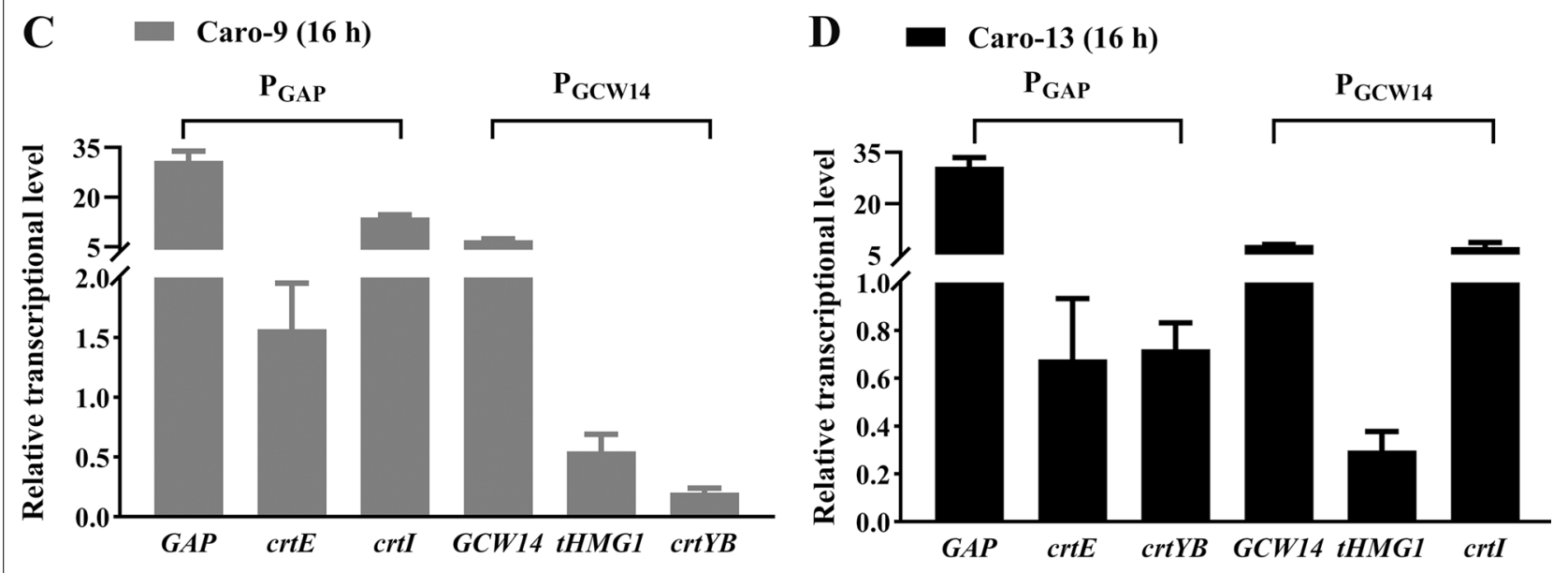

Genes

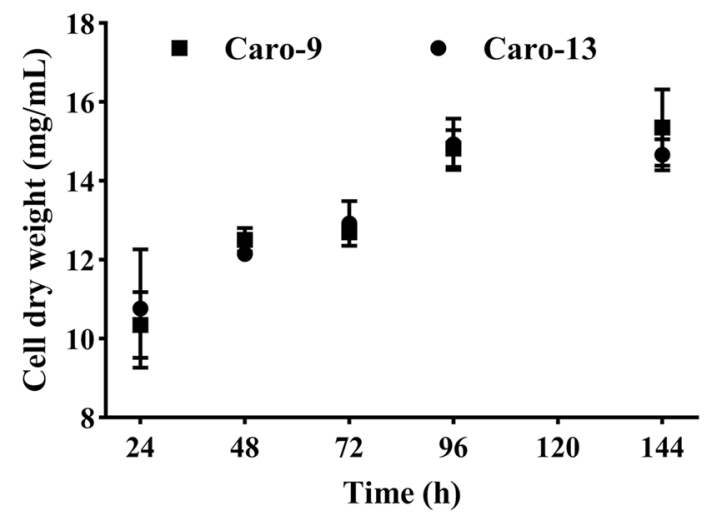

Fig. 6 The competitive effect existing in Caro-13 and Caro-9 strains. A A significant difference in the production of $\beta$-carotene in both strains. B The growth curves of both strains. C The relative transcriptional levels of the exogenous genes in the Caro- 9 strain after $16 \mathrm{~h}$ growth. $\mathbf{D}$ The relative transcriptional levels of the exogenous genes in the Caro-13 strain after $16 \mathrm{~h}$ growth. The ACT1 gene was used as the reference gene. Error bars indicate the SD for samples tested in triplicate

the transcriptional levels of two exogenous genes controlled by the same promoter behaved differently. As shown in Fig. $6 \mathrm{C}$, although an endogenous gene (GAP) and two exogenous genes ( $c r t E$ and $c r t I$ ) were all driven by $\mathrm{P}_{\mathrm{GAP}}$ in the Caro- 9 strain, the transcriptional levels of both exogenous genes were much lower than that of GAP, presenting a significant "competitive effect". In addition, the transcriptional levels of $c r t E$ and $c r t I$ were also different. So were GCW14, $\operatorname{crt} Y B$, and $t H M G$ 1controlled by $\mathrm{P}_{\mathrm{GCW} 14}$. A similar phenomenon was also observed in the Caro-13 strain (Fig. 6D). Such a "competitive effect" when the same promoter was used multiple times in one yeast strain resulted in a lower expression level of the related gene than expected. It might be an important factor limiting the $\beta$-carotene yields of engineering strains constructed in this study.

\section{Discussion}

The strong promoter is an indispensable element in the engineering retrofit and application of yeast. Due to the lack of basic research compared with $S$. cerevisiae, the availability of strong promoter is scarce in P. pastoris, which seriously restricts the subsequent application.

In this study, by analyzing the RNA-seq data of GS115 WT strain in the stationary phase under different media (YPD, YPG, and YPM), ten strong endogenous promoters $\left(\mathrm{P}_{\mathrm{GCW} 14}, \mathrm{P}_{0627}, \mathrm{P}_{0019}, \mathrm{P}_{\mathrm{GAP}}, \mathrm{P}_{0407}, \mathrm{P}_{0392}, \mathrm{P}_{0230}, \mathrm{P}_{0208}\right.$, $\mathrm{P}_{0785}$, and $\mathrm{P}_{0107}$ ) which were not affected by carbon sources were screened out. Except for $\mathrm{P}_{\mathrm{GCW} 14}$ and $\mathrm{P}_{\mathrm{GAP}}$, eight of them were first reported here. Five $\left(\mathrm{P}_{0019}, \mathrm{P}_{0392}\right.$, $\mathrm{P}_{0230}, \mathrm{P}_{0785}$, and $\left.\mathrm{P}_{0107}\right)$ were identified as strong constitutive promoters, and two $\left(\mathrm{P}_{0627}\right.$ and $\left.\mathrm{P}_{0208}\right)$ as growthdependent strong promoters. The growth-dependent 
transcriptional behavior of $\mathrm{P}_{0627}$ or $\mathrm{P}_{0208}$ makes it a good selection for the expression of toxic foreign proteins in P. pastoris. $\mathrm{P}_{0407}$ showed a similar trend as $\mathrm{P}_{0627}$ and $\mathrm{P}_{0208}$ in $\beta$-galactosidase activity. However, the transcriptional level of $\mathrm{P}_{0407}$-lac $Z$ was higher than that of $A C T 1$ at $16 \mathrm{~h}$, indicating this promoter was not a strictly growthdependent promoter. In addition, in our study, the activity of $\mathrm{P}_{\mathrm{GCW} 14}$ was lower than that of $\mathrm{P}_{\mathrm{GAP}}$ in YPD broth and similar to that of $\mathrm{P}_{\mathrm{GAP}}$ in YPG broth when measured with the $\beta$-galactosidase activity assay. These results were not consistent with the previous report that $\mathrm{P}_{\mathrm{GCW} 14}$ activity was much higher than $\mathrm{P}_{\mathrm{GAP}}$ by EGFP reporter in YPD or YPD broth [23].

However, the results of RT-qPCR and the $\beta$-galactosidase activity did not agree in all cases. For example, the transcriptional level of $\mathrm{P}_{0407}$-lac $Z$ was much higher than that of $\mathrm{P}_{\mathrm{GAP}}$-lac $Z$ when the relative transformants were cultured in YPG or YPM broth. However, its related $\beta$-galactosidase activity was much lower than $\mathrm{P}_{\mathrm{GAP}} . \mathrm{P}_{0107}$ presented the lowest transcriptional level at $60 \mathrm{~h}$, but its corresponding $\beta$-galactosidase activity was not the lowest (Fig. 2). These results agree with the suggestion of previous reports that it was not that the higher of transcriptional level, the higher of protein expression level $[29,30]$.

In this study, a heterogenous biosynthetic pathway of $\beta$-carotene containing four genes was used to further evaluate the properties of six strong endogenous promoters $\left(\mathrm{P}_{\mathrm{GAP}}, \mathrm{P}_{\mathrm{GCW} 14}, \mathrm{P}_{0208}, \mathrm{P}_{0019}, \mathrm{P}_{0230}\right.$, and $\left.\mathrm{P}_{0107}\right)$. The Caro14 strain contributed the highest yield of $\beta$-carotene $(1.07 \mathrm{mg} / \mathrm{g} \mathrm{DCW})$. It is higher than the yield in S. cerevisiae containing integrated carotenogenic gene cassettes crtYB/I/E/tHMG1 (501 $\mu \mathrm{g} / \mathrm{g}$ DCW) [31], suggesting that $P$. pastoris might have the advantages to be engineered as a carotene producer.

In addition, the competitive effect was first evaluated in this study. It was found that using the same promoter multiple times in one strain could lead to a significant decrease of the expression level of the target gene, reminding a careful evaluation is required before using a promoter in this way.

Some reports considered a $500 \mathrm{bp}$ upstream sequence covering the whole promoter region of most genes in $S$. cerevisiae [32, 33]. As the most known strong constitutive promoter $\mathrm{P}_{\mathrm{GAP}}$ in $P$. pastoris, its' sequence length is $477 \mathrm{bp}$. It should be noted that the intergenic region between GAP and its neighbor gene was $1576 \mathrm{bp}$. On the contrary, the sequence length of another wellknown strong inducible promoter, $\mathrm{P}_{\mathrm{AOX} 1}$, is $939 \mathrm{bp}$ in

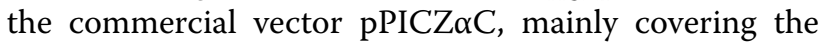
intergenic region between $A O X 1$ and its neighbor gene (998 bp). The study of $\mathrm{P}_{\mathrm{AOX} 1}$ showed that the region -1055 to -809 and -653 to -514 significantly affects the promoter activity [34]. In our study, the $500 \mathrm{bp}$ upstream sequence of candidate gene was amplified to act as a promoter. However, the lengths of the intergenic region of some genes are more than $500 \mathrm{bp}$, which might cause incomplete promoter elements like $\mathrm{P}_{\mathrm{AOX} 1}$, thereby affecting their normal functions. The corresponding intergenic regions of six selected promoters are over $500 \mathrm{bp}$ except $\mathrm{P}_{0208}$, reminding the possibility that several key regulatory elements might not be included in the 500 bp sequence (Additional file 4). The promoter length would be appropriately extended in the follow-up study to explore whether it will significantly impact promoter activity.

\section{Method and materials}

Strains, vectors, and media

All strains used in this study are listed in Additional file 5. Escherichia coli TG1 was used to amplify plasmids in LB medium $(0.5 \%$ yeast extract, $1 \%$ tryptone, $1 \%$ sodium chloride) containing $100 \mu \mathrm{g} / \mathrm{mL}$ ampicillin, zeocin, or $50 \mu \mathrm{g} / \mathrm{mL}$ kanamycin sulfate, and incubated at $37^{\circ} \mathrm{C}$. The yeast mutants were derived from the $P$. pastoris GS115 wild-type strain. All yeast strains, unless otherwise specified, were grown in YPD medium (1\% yeast extract, $2 \%$ peptone, $2 \%$ glucose) at $30^{\circ} \mathrm{C}$.

\section{Measurement of the yeast growth curves in different carbon source broths}

The GS115 WT strain was pre-cultured in $5 \mathrm{~mL}$ YPD broth at $30{ }^{\circ} \mathrm{C}, 220 \mathrm{rpm}$ for $24 \mathrm{~h}$ and followed by inoculating to an initial $\mathrm{OD}_{600}$ of $0.1 \mathrm{in} 250 \mathrm{~mL}$ shaking flasks containing $50 \mathrm{~mL}$ YPD (2\% glucose), YPG ( $2 \%$ glycerol), or YPM ( $1 \%$ methanol) for $72 \mathrm{~h}$. The optical absorbance $\left(\mathrm{OD}_{600}\right)$ of the culture was detected by an Evolution ${ }^{\mathrm{TM}} 220$ spectrophotometer (Thermo Fisher Scientific Inc., USA), and each medium had three replicates.

\section{RNA-seq analysis}

Three independent clones of the GS115 WT strain were incubated in $5 \mathrm{~mL}$ YPD broth for $24 \mathrm{~h}$. The pre-cultured pellet was washed with presterilized water and transferred into YPD, YPG, or YPM broth for incubating. The yeast cells (total $\mathrm{OD}_{600}$ of 16) were harvested by centrifugation $\left(5000 \mathrm{~g}\right.$ for $5 \mathrm{~min}, 4{ }^{\circ} \mathrm{C}$ ) at $36 \mathrm{~h}$ when they entered the stationary phase. Total RNA was isolated using a Yeast RNA kit (Omega Bio-Tek Inc., USA) through the operation manual. The residuary genomic DNA was eliminated using a DNase I treatment (Takara Bio Inc., Japan). The qualified RNA samples determined with Bioanalyzer 2100 (Agilent Technologies, USA) were used for library construction with the sequencing platform BGISEQ-500 (BGI Shenzhen, China). Compared to the genome, the average comparison rate of the sample is $97.13 \%$, and 
the average comparison rate of the compared gene set is $82.58 \%$. All the generated raw sequencing reads were filtered to remove reads with adaptors, reads with more than $10 \%$ unknown bases, and low-quality reads. Clean reads were then obtained and stored in FASTQ format. The clean reads were mapped to the genome of GS115 by HISAT [35]. The software package RSEM [36] was used to quantify the gene expression level. The ratio of FPKM for candidate genes to that for $A C T 1$ was used as the relative fold change for RNA-seq data treatment.

\section{Real-time quantitative PCR (RT-qPCR) analysis}

The methods for obtaining pure total RNA were mentioned above. After DNase I treatment, the absence of DNA contamination was confirmed by PCR using a pair of genomic primers, and the genome of the GS115 WT strain was used as a positive control. 800 ng of total RNA was used to reverse transcription to generate cDNA with HiScript II Reverse Transcriptase (Vazyme Biotech Co., Ltd., China). RT-qPCR was carried out on a Mastercycler $^{\circledR}$ ep gradient $\mathrm{S}$ instrument (Eppendorf, Hamburg, Germany) with $2 \times$ ChemQ SYBR qPCR Mester Mix (Vazyme Biotech Co., Ltd., China). The ACT1 gene was chosen as an internal control to normalize the relative expression levels of target genes. All reactions were performed in three replicates. A $\Delta \Delta \mathrm{Ct}$ method was used for the relative fold change analysis [37].

\section{Construction of the vectors containing $\mathrm{P}_{\mathrm{xxx}}$-lac $Z$ and yeast transformation}

The genomic DNA of E. coli BL21 (DE3) was used as a template to amplify the open reading frame (ORF) of lacZ. DNA fragments of the integration site ( $A O X 1$ promoter, which helped the plasmid inserted into the chromosome) were amplified from GS115. ADH1 terminator $\left(\mathrm{T}_{\mathrm{ADH1}}\right)$ was amplified from the genomic DNA of S. cerevisiae BY4741. The fragment of ori and zeocin-resistant marker came from the commercial plasmid pPICZ $\alpha \mathrm{C}$ (Invitrogen Corporation, USA). All the fragments were amplified with Hieff Canace ${ }^{\mathrm{TM}}$ high-fidelity DNA Polymerase (Yeasen, China) and then be linked by the homologous arm with pEASY ${ }^{\circledR}$-Basic Seamless Cloning and Assembly Kit (TransGen Biotech Co., Ltd, China) to con-

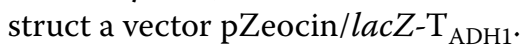

The promoter fragments of candidates were amplified from the genomic DNA of P. pastoris GS115 by PCR and then inserted into the HindIII site of pZeocin/lacZ- $\mathrm{T}_{\mathrm{ADH} 1}$ with seamless cloning to yield vector $\mathrm{pZeocin} / \mathrm{P}_{\mathrm{XXX}}$-lacZ$\mathrm{T}_{\mathrm{ADH} 1}\left(\mathrm{P}_{\mathrm{XXX}}\right.$ indicates the name of candidate promoters).

The linearized vector $\mathrm{pZeocin} / \mathrm{P}_{\mathrm{XxX}}-$ lacZ- $\mathrm{T}_{\mathrm{ADH} 1}$ with PmeI (located in the middle of $A O X 1$ promoter locus) digested were transferred into the GS115 cells by electro-transformation and integrated into the genome by homologous recombination [38]. The strains containing $\mathrm{P}_{\mathrm{XxX}}$-lac $Z$ were selected from the agar plates containing zeocin $(0.1 \mathrm{mg} / \mathrm{mL})$ and verified by PCR. The template came from colony or genomic DNA. The colony was boiled in water for $5 \mathrm{~min}$ before PCR and the genomic DNA was extracted as the previous report [39].

\section{$\beta$-Galactosidase activity assay}

The $\beta$-galactosidase activity was assayed according to the previous report with slight modification [40]. Briefly, the yeast cells (total $\mathrm{OD}_{600}$ of 3 ) were collected. The supernatant was discarded by centrifuge, and the pellet was resuspended in $1 \mathrm{~mL} \mathrm{Z} \mathrm{buffer}\left(60 \mathrm{mM} \mathrm{Na}_{2} \mathrm{HPO}_{4}, 40 \mathrm{mM}\right.$ $\mathrm{NaH}_{2} \mathrm{PO}_{4}, 10 \mathrm{mM} \mathrm{KCl}$, and $1 \mathrm{mM} \mathrm{MgSO}$ ) and diluted to make the final $\mathrm{OD}_{600}$ of $0.2-0.6$. Take suitable volumes of the above cells into a $2 \mathrm{~mL}$ Eppendorf tube, and make up to $1 \mathrm{~mL}$ with Z Buffer. Add $25 \mu \mathrm{L} 0.1 \%$ SDS and 50 $\mu \mathrm{L}$ chloroform, vortex for $30 \mathrm{~s}$, and incubate at $30^{\circ} \mathrm{C}$ for $15 \mathrm{~min}$. The reaction was started through the addition of $200 \mu \mathrm{L}$ of $4 \mathrm{mg} / \mathrm{mL}$ onitrophenyl- $\beta$ - $D$-galactopyranoside (ONPG) solution at $30{ }^{\circ} \mathrm{C}$ and stopped by the addition of $500 \mu \mathrm{L}$ of $1 \mathrm{M} \mathrm{NaCO}_{3}$. After removal of cell debris by centrifugation, the $\mathrm{OD}_{420}$ and $\mathrm{OD}_{550}$ of the reaction solution were detected by Evolution ${ }^{\mathrm{TM}} 220$ spectrophotometer, and the relative activity of $\beta$-galactosidase was calculated using the formula below:

$$
\begin{aligned}
\text { Miller units }= & 1000 \times\left(\mathrm{OD}_{420}-1.75 \times \mathrm{OD}_{550}\right) / \\
& \left(\mathrm{V} \times \mathrm{OD}_{600} \times \mathrm{t}\right)
\end{aligned}
$$

$\mathrm{T}$ is the reaction time $(\mathrm{min})$ and $\mathrm{V}$ is the volume $(\mathrm{mL})$ of culture used for the assay.

\section{Construction of promoter library in the $\beta$-carotene biosynthetic pathway}

The vector pMRI-34-crtE-tHMG1 and vector pMRI35-crtYB-crtI were the kind gifts from Hongwei Yu's lab [41]. The two gene cassettes with opposite directions of $t H M G 1 / \operatorname{crtE}$ or $\mathrm{crtI} / \mathrm{crtYB}$ containing the promoter, ORF, and terminator were amplified from the above vectors. The $A O X 1$ promoter (located in GS115 chromosome 4) and ENO2 promoter (located in GS115 chromosome 3) were chosen as the integration site. The ble (coding zeocin-resistant protein in E. coli and yeast) and kan (coding kanamycin-resistant protein in E. coli and G418-resistant protein in yeast, respectively) were chosen as screening markers. All those fragments were linked with the homologous arm by seamless cloning to yield vector pZeocin/crtE-tHMG1 and vector pG418/crtYB-crtI.

The candidate promoters $\left(\mathrm{P}_{0107}, \mathrm{P}_{\mathrm{GCW} 14}, \mathrm{P}_{0019}, \mathrm{P}_{\mathrm{GAP}}\right.$, $\mathrm{P}_{0208}$, and $\mathrm{P}_{0230}$ ) were amplified from the genomic DNA of GS115 by PCR. Two promoters in opposite directions were co-amplified by fusion PCR. Then a pool of 
combinations with two reversed promoters was obtained. Those promoters were inserted into BamHI/NotI sites of vector $\mathrm{pZeocin} /$ crtE-tHMG1 and vector $\mathrm{pG} 418 / \mathrm{crtYB}$ crtI with seamless cloning to yield vector $\mathrm{pZeocin} / \mathrm{P}_{\mathrm{XXX}}{ }^{-}$ $c r t E-\mathrm{P}_{\mathrm{YYY}}-t H M G 1$ and vector $\mathrm{pG} 418 / \mathrm{P}_{\mathrm{XXX}}-c r t Y B-\mathrm{P}_{\mathrm{YYY}}$ - $\operatorname{crtI}\left(\mathrm{P}_{\mathrm{XXX}}\right.$ and $\mathrm{P}_{\mathrm{YYY}}$ indicate the name of candidate promoters). The vector $\mathrm{pZeocin} / \mathrm{P}_{\mathrm{XXX}}-c r t E-\mathrm{P}_{\mathrm{YYY}}-t H M G 1$ was linearized with PmeI and then transferred into the GS115 cell by electro-transformation. All the transformants grown on the agar plates containing zeocin were selected and co-cultured for the next round of electrotransformation with linearized $\mathrm{pG} 418 / \mathrm{P}_{\mathrm{XXX}}-\mathrm{crt} Y B-\mathrm{P}_{\mathrm{YYY}}$ -crtI by ScaI in ENO2 promoter. The transformants with different colors on the agar plates containing G418 $(0.25 \mathrm{mg} / \mathrm{mL})$ were picked out. The promoter combinations were verified by PCR.

\section{Measurement of the $\beta$-carotene production}

The extraction and analysis of $\beta$-carotene were performed according to a previous report [41]. Briefly, the $\beta$-carotene engineering strains were pre-cultured in $5 \mathrm{~mL}$ YPD broth at $30{ }^{\circ} \mathrm{C}, 220 \mathrm{rpm}$ for $24 \mathrm{~h}$. Precultures were inoculated to an initial $\mathrm{OD}_{600}$ of 0.05 in $20 \mathrm{~mL}$ of YPD broth with 100 $\mathrm{mL}$ flasks and grown under the same condition for $120 \mathrm{~h}$. Samples were taken every $24 \mathrm{~h}$ to determine the DCW and $\beta$-carotene yield. The carotenoids were co-extracted using hot $\mathrm{HCl}$-acetone. The analyses of $\beta$-carotene were performed on an HPLC system (LC 20AT) equipped with a Supersil ODS2 C18 column $(4.6 \mathrm{~mm} \times 250 \mathrm{~mm})$. The mobile phase is composed of acetonitrile, methanol, and isopropanol with a volume ratio of $5: 3: 2$, followed by a flow rate of $1 \mathrm{~mL} / \mathrm{min}$ at $40{ }^{\circ} \mathrm{C}$. The UV/VIS signals were detected at $450 \mathrm{~nm}$, and the analysis time of each sample is $40 \mathrm{~min}$. The standard product of $\beta$-carotene was purchased from Solarbio (Beijing Solarbio Science \& Technology Co., Ltd., China). The standard curve of concentration with the peak area was verified by triplicate.

\section{Abbreviations \\ MUT:The methanol utilization; AOX1: Alcohol oxidase 1; FLD1: Formalde- hyde dehydrogenase 1; DAS: Dihydroxyacetone synthase; PEX8: Peroxisomal matrix protein; AOX2: Alcohol oxidase 2; FPKM: Fragments per kilobase of transcript per million base pairs sequenced; RT-qPCR: Real-time quantita- tive PCR; GPI: Glycosylphosphatidylinositol; GS: Glutamine synthetase; DCW: Dry cell weight; ORF: Open reading frame; $\mathrm{T}_{\mathrm{ADH}}$ : $A D H 1$ terminator; ONPG: Onitrophenyl- $\beta$-D-galactopyranoside.}

\section{Supplementary Information}

The online version contains supplementary material available at https://doi. org/10.1186/s12934-021-01648-6.

Additional file 1. Identified promoter candidates in P. pastoris GS115. Additional file 2. Evaluation of the growth-dependent strong promoter $\mathrm{P}_{0208}$ and $\mathrm{P}_{0627}$. (A) The relative transcriptional levels of 0627, 0208,and 0407 in YPD broth (B) The relative transcriptional levels of 0627,0208, and 0407 in YPG broth (C) The relative transcriptional levelsof 0627, 0208, and 0407 in YPM broth. Additional file 3. Primers used for RT-qPCR and colony verification. Additional file 4. Sequence length of the intergenic region of selected genes. Additional file 5. Strains and vectors used in this study.

\section{Acknowledgements}

Not applicable.

\section{Authors' contributions}

WWD, QCZ and WJG conceived the original research idea. WWD, QCZ, MHZ, and ZYJ carried out all the experiments. WWD and QCZ drafted the initial manuscript. WJG reviewed and revised the manuscript. WWD and QCZ contributed equally to this article. All authors read and approved the final manuscript.

\section{Funding}

This work was supported by the National Key R\&D Program of China (2019YFA0905400, 2018YFA0903200).

\section{Availability of data and materials}

The datasets used and/or analyzed during the current study are available from the corresponding author on reasonable request.

\section{Declarations}

Ethics approval and consent to participate

Not applicable.

\section{Consent for publication}

Not applicable.

\section{Competing interests}

The authors declare that they have no competing interests.

\section{Author details}

${ }^{1}$ Institute of Pharmaceutical Biotechnology and The Children's Hospital, Zhejiang University School of Medicine, Hangzhou 310058, China. ${ }^{2}$ Department of Pharmacy, The First Affiliated Hospital, Zhejiang University, Hangzhou 310003, China.

Received: 16 April 2021 Accepted: 31 July 2021

Published online: 09 August 2021

\section{References}

1. Parashar D, Satyanarayana T. Enhancing the production of recombinant acidic alpha-amylase and phytase in Pichia pastoris under dual promoters [constitutive (GAP) and inducible (AOX)] in mixed fed batch high cell density cultivation. Process Biochem. 2016;51:1315-22.

2. Wriessnegger T, Augustin P, Engleder M, Leitner E, Muller M, Kaluzna I, Schurmann M, Mink D, Zellnig G, Schwab H, Pichler H. Production of the sesquiterpenoid (+)-nootkatone by metabolic engineering of Pichia pastoris. Metab Eng. 2014;24:18-29.

3. Araya-Garay JM, Feijoo-Siota L, Rosa-dos-Santos F, Veiga-Crespo P, Villa TG. Construction of new Pichia pastoris X-33 strains for production of lycopene and beta-carotene. Appl Microbiol Biotechnol. 2012;93:2483-92.

4. Bhataya A, Schmidt-Dannert C, Lee PC. Metabolic engineering of Pichia pastoris X-33 for lycopene production. Process Biochem. 2009:44:1095-102.

5. Araya-Garay JM, Ageitos JM, Vallejo JA, Veiga-Crespo P, Sanchez-Perez A, Villa TG. Construction of a novel Pichia pastoris strain for production of xanthophylls. AMB Exp. 2012;2:1-8.

6. Meesapyodsuk D, Chen Y, Ng SH, Chen JN, Qiu X. Metabolic engineering of Pichia pastoris to produce ricinoleic acid, a hydroxy fatty acid of industrial importance. J Lipid Res. 2015;56:2102-9.

7. Jeong E, Shim WY, Kim JH. Metabolic engineering of Pichia pastoris for production of hyaluronic acid with high molecular weight. J Biotechnol. 2014;185:28-36. 
8. Liu XB, Liu M, Tao XY, Zhang ZX, Wang FQ, Wei DZ. Metabolic engineering of Pichia pastoris for the production of dammarenediol-II. J Biotechnol. 2015;216:47-55.

9. Xu N, Zhu JX, Zhu QY, Xing YZ, Cai MH, Jiang TY, Zhou M, Zhang YX. Identification and characterization of novel promoters for recombinant protein production in yeast Pichia pastoris. Yeast. 2018;35:379-85.

10. Vogl T, Glieder A. Regulation of Pichia pastoris promoters and its consequences for protein production. N Biotechnol. 2013;30:385-404.

11. Portela RMC, VogI T, Ebner K, Oliveira R, Glieder A. Pichia pastoris Alcohol Oxidase 1 (AOX1) Core promoter engineering by high resolution systematic mutagenesis. Biotechnol J. 2018;13:1700340.

12. Resina D, Cos O, Ferrer P, Valero F. Developing high cell density fed-batch cultivation strategies for heterologous protein production in Pichia pastoris using the nitrogen source-regulated FLD1 promoter. Biotechnol Bioeng. 2005;91:760-7.

13. Tschopp JF, Brust PF, Cregg JM, Stillman CA, Gingeras TR. Expression of the lacZ gene from two methanol-regulated promoters in Pichia pastoris. Nucleic Acids Res. 1987;15:3859-76.

14. Cereghino JL, Cregg JM. Heterologous protein expression in the methylotrophic yeast Pichia pastoris. FEMS Microbiol Rev. 2000;24:45-66.

15. Cregg JM, Madden KR, Barringer KJ, Thill GP, Stillman CA. Functional characterization of the two alcohol oxidase genes from the yeast Pichia pastoris. Mol Cell Biol. 1989;9:1316-23.

16. Hartner FS, Glieder A. Regulation of methanol utilisation pathway genes in yeasts. Microb Cell Fact. 2006;5:39.

17. Sears IB, O'Connor J, Rossanese OW, Glick BS. A versatile set of vectors for constitutive and regulated gene expression in Pichia pastoris. Yeast. 1998; 14:783-90.

18. Vassileva A, Chugh DA, Swaminathan S, Khanna N. Expression of hepatitis B surface antigen in the methylotrophic yeast Pichia pastoris using the GAP promoter. J Biotechnol. 2001;88:21-35.

19. Waterham HR, Digan ME, Koutz PJ, Lair SV, Cregg JM. Isolation of the Pichia pastoris glyceraldehyde-3-phosphate dehydrogenase gene and regulation and use of its promoter. Gene. 1997;186:37-44.

20. Doring F, Klapper M, Theis S, Daniel H. Use of the glyceraldehyde-3-phosphate dehydrogenase promoter for production of functional mammalian membrane transport proteins in the yeast Pichia pastoris. Biochem Biophys Res Commun. 1998;250:531-5.

21. Qin XL, Qian JC, Yao GF, Zhuang YP, Zhang SL, Chu J. GAP promoter library for fine-tuning of gene expression in Pichia pastoris. Appl Environ Microb. 2011;77:3600-8.

22. Ahn J, Hong J, Lee H, Park M, Lee E, Kim C, Choi E, Jung J, Lee H. Translation elongation factor 1-alpha gene from Pichia pastoris: molecular cloning, sequence, and use of its promoter. Appl Microbiol Biotechnol. 2007;74:601-8.

23. Liang SL, Zou CJ, Lin Y, Zhang XW, Ye YR. Identification and characterization of P-GCW14: a novel, strong constitutive promoter of Pichia pastoris. Biotechnol Lett. 2013;35:1865-71.

24. Stadlmayr G, Mecklenbrauker A, Rothmuller M, Maurer M, Sauer M, Mattanovich D, Gasser B. Identification and characterisation of novel Pichia pastoris promoters for heterologous protein production. J Biotechnol. 2010;150:519-29.

25. Zhu T, Guo M, Zhuang Y, Chu J, Zhang S. Understanding the effect of foreign gene dosage on the physiology of Pichia pastoris by transcriptional analysis of key genes. Appl Microbiol Biotechnol. 2011;89:1127-35.

26. Schwarzhans JP, Wibberg D, Winkler A, Luttermann T, Kalinowski J, Friehs K. Non-canonical integration events in Pichia pastoris encountered during standard transformation analysed with genome sequencing. Sci Rep. 2016;6:38952.

27. Xie WP, Liu M, Lv XM, Lu WQ, Gu JL, Yu HW. Construction of a controllable beta-carotene biosynthetic pathway by decentralized assembly strategy in Saccharomyces cerevisiae. Biotechnol Bioeng. 2014;111:125-33.

28. Ledetzky N, Osawa A, Iki K, Pollmann H, Gassel S, Breitenbach J, Shindo K, Sandmann G. Multiple transformation with the crtYB gene of the limiting enzyme increased carotenoid synthesis and generated novel derivatives in Xanthophyllomyces dendrorhous. Arch Biochem Biophys. 2014;545:141-7.

29. Koussounadis A, Langdon SP, Um IH, Harrison DJ, Smith VA. Relationship between differentially expressed mRNA and mRNA-protein correlations in a xenograft model system. Sci Rep UK. 2015;5:1-9.

30. Liu YS, Beyer A, Aebersold R. On the dependency of cellular protein levels on mRNA abundance. Cell. 2016;165:535-50.

31. Verwaal R, Wang J, Meijnen JP, Visser H, Sandmann G, van den Berg JA, van Ooyen AJJ. High-level production of beta-carotene in Saccharomyces cerevisiae by successive transformation with carotenogenic genes from Xanthophyllomyces dendrorhous. Appl Environ Microb. 2007;73:4342-50.

32. Agmon N, Mitchell LA, Cai Y, Ikushima S, Chuang J, Zheng A, Choi WJ, Martin JA, Caravelli K, Stracquadanio G, Boeke JD. Yeast golden gate (yGG) for the efficient assembly of $S$. cerevisiae transcription units. ACS Synth Biol. 2015;4:853-9.

33. Garcia-Ruiz E, Auxillos J, Li T, Dai J, Cai Y. YeastFab: high-throughput genetic parts construction, measurement, and pathway engineering in yeast. Methods Enzymol. 2018;608:277-306.

34. Xuan YJ, Zhou XS, Zhang WW, Zhang X, Song ZW, Zhang YX. An upstream activation sequence controls the expression of $A O X 1$ gene in Pichia pastoris. FEMS Yeast Res. 2009;9:1271-82.

35. Kim D, Landmead B, Salzberg SL. HISAT: a fast spliced aligner with low memory requirements. Nat Methods. 2015;12:357-U121.

36. Li B, Dewey CN. RSEM: accurate transcript quantification from RNA-Seq data with or without a reference genome. BMC Bioinform. 2011;12:1-16.

37. Livak KJ, Schmittgen TD. Analysis of relative gene expression data using real-time quantitative PCR and the 2(T)(-Delta Delta C) method. Methods. 2001;25:402-8.

38. Wu SX, Letchworth GJ. High efficiency transformation by electroporation of Pichia pastoris pretreated with lithium acetate and dithiothreitol. Biotechniques. 2004;36:152-4.

39. Looke M, Kristjuhan K, Kristjuhan A. Extraction of genomic DNA from yeasts for PCR-based applications. BioTechniques. 2017;62:325-8.

40. Nambu-Nishida Y, Sakihama Y, Ishii J, Hasunuma T, Kondo A. Selection of yeast Saccharomyces cerevisiae promoters available for xylose cultivation and fermentation. J Biosci Bioeng. 2018;125:76-86.

41. Xie W, Liu M, Lv X, Lu W, Gu J, Yu H. Construction of a controllable betacarotene biosynthetic pathway by decentralized assembly strategy in Saccharomyces cerevisiae. Biotechnol Bioeng. 2014;111:125-33.

\section{Publisher's Note}

Springer Nature remains neutral with regard to jurisdictional claims in published maps and institutional affiliations.

Ready to submit your research? Choose BMC and benefit from:

- fast, convenient online submission

- thorough peer review by experienced researchers in your field

- rapid publication on acceptance

- support for research data, including large and complex data types

- gold Open Access which fosters wider collaboration and increased citations

- maximum visibility for your research: over $100 \mathrm{M}$ website views per year

At BMC, research is always in progress.

Learn more biomedcentral.com/submissions 